\title{
The prospects of polymeric materials (PMs) in assembling the solar water-thermal collectors (SCs). Comparative data analysis and exploratory research of promising solutions
}

\author{
A. V. Doroshenko ${ }^{凶}$, V. F. Khalak
}

${ }^{1}$ Odessa National Academy of Food Technologies, 112 Kanatnaya str., Odessa, 65039, Ukraine

$\triangle$ e-mail: dor_av43@i.ua

Concerning the construction of a solar water-thermal collector - the analysis of the applied polymeric materials has been performed in relation to manufacturing of its main parts - the heat absorber and the transparent cover. The use of polymers in the construction of the solar water-thermal collector allows one to lower the manufacturing costs, make the collector light-weight and reduce its price. An analytical review based on the domestic and foreign research and development, published in scientific journals over the past few years, which the authors hope shall be a useful reading in the design-engineering departments responsible for constructing the polymeric solar collectors is the goal of the present work, along with the comparative analysis provided further on the collectors' efficiency for making a choice of material and the solar energy capture systems' testing methodology. As the fundamental direction of further improvement of the polymeric solar collectors, the authors aim at: elimination of the air gap between the heat absorber and the transparent cover, leading to construction of a monoblock solar collector; optimization of the heat absorber's and the transparent cover's flow channels in solar water-thermal collectors, which concern their compages as well as the size and geometry of the hydraulic collector; optimization of the transparent cover's channels size as the means of air circulation, which lowers summary heat losses in solar water-thermal collectors; studying the evenness of the heating agent's distribution in the heat absorber's channels out in the field, to pursue the improvements in efficiency of the solar water-thermal collectors, and to avoid the heat shock of a solar water-thermal collector's structural elements upon uneven warming-up. In the present work the analysis has been performed on the summary heat losses (convective and radiation losses realized from the solar collector's heated-up elements) which depend on a polymeric solar collector's operating conditions and geometrics as well as on a solar energy capture system's external environment; a tryout facility has been built, affording a comparative analysis of various solutions; and the main objectives of further research in the field of polymeric solar collectors, particularly, the questions on improvement of their assembly realisation, and reliability of multifunctional solar energy capture systems have been formulated.

Keywords: Solar energy capture system; polymeric solar collector; heat absorber; transparent cover; summary heat losses.

\section{Сонячні полімерні рідинні колектори. Аналіз наявних результатів, нові рішення}

\section{О. В. Дорошенко, В. Ф. Халак}

Одеська національна академія харчових технологій, вул. Канатна, 112, м. Одеса, 65039, Україна

\begin{abstract}
Стосовно до конструкиї рідинного сонячного колектора виконаний аналіз застосовуваних полімерних матеріалів для виготовлення його основних елементів, - теплоприймача і прозорого покриття. Використання полімерів в конструкиї сонячного колектора дозволяє знизити витрати на виробництво, знизити його вагу $i$ вартість. Метою изієї роботи є аналітичний огляд, виконаний на основі досліджень і розробок останніх років у вітчизняній та закордонній науковій літературі, використовуваних при конструюванні рідинних сонячних колекторів полімерних матеріалів і порівняння їх впливу на ефективність колектора для подальшого вибору матеріалу та тестування сонячних систем. За основними напрямками подальшого вдосконалення полімерних рідинних сонячних колекторів (СК-р) авторами вибрано усунення повітряного зазору між теплоприймачем ТП $i$ прозорим покриттям ПП та створення СК-р у вигляді єдиної моноблоковой структури; оптимізація розмірів каналів теплоприймача та прозорого покриття полімерного СК-р, експериментальне дослідження рівномірності розподілу теплоносія в каналах теплоприймача ТП, з метою підвищення ефективності СК-р $i$ запобігання теплового шоку елементів конструкиї полімерного СК-р при їх нерівномірному розігріванні. $B$ роботі виконано аналіз сумарних термічних втрат (конвективні та радіаційні втрати від нагрітих елементів сонячного колектора) в залежності від режимних $і$ геометричних параметрів полімерних СК, а також умов експлуатації сонячних систем. Розроблено експериментальне обладнання, щзо дозволяє проводити порівняльний аналіз різних рішень $і$ сформульовані основні завдання подальших досліджень в області вдосконалення конструктивного оформлення і підвищення надійності полімерних сонячних СК для багатофункціональних сонячних систем.
\end{abstract}


Ключові слова: Сонячна система, полімерний сонячний колектор, теплоприймач, прозоре покриття, сумарні термічні втрати.

(C) The Author(s) 2018. This article is an open access publication

This work is licensed under the Creative Commons Attribution 4.0 International License (CC BY) http://creativecommons.org/licenses/by/4.0/

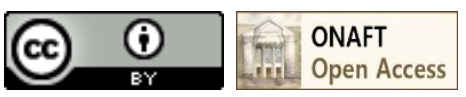

\section{Abbreviations}

WHS -water-heating system

SWHS - solar water-heating system

$\mathrm{SC}$ - solar water-thermal collector

$\mathrm{HA}$ - heat absorber

TC - transparent cover

$\mathrm{PM}$ - polymer material

HWT - hot water tank

\section{Introduction}

The water-heating systems come second after the airconditioning installations as the most energy-hungry ones in residential housing. The total consumption of electricity can be reduced by installing the hot-water system equipped with solar collectors, having a payback period within the range of 2-4 years (it varies on the complexity of the system). For building an SWHS, the flat-plate solar collectors are being used almost routinely due to their low price, in contrast with their more expensive counterparts the vacuum- or concentration-type of a collector. It is wellknown as also traditional for a metal-made SC to be the most expensive component of an SWHS, in which case the price of the latter varies upon the size and actual materials used.

For manufacturing the main parts of a solar liquidbased thermal collector it is the rule that non-ferrous metals (such as copper, aluminium, etc) are being used, while stainless steel comes for a heat absorber, and low-iron glass for a transparent cover. The cost of those colour metals the solar collectors must have incorporated, and, moreover, that of the enduring process of production is for many an insurmountable barrier to afford a purchase. While the copper and aluminium prices are on a rise for the last few years [1], cheap polymeric materials look rather promising against this backdrop to endeavour into mass-producing of the low-cost SCs. By turning to the polymeric-made SCs, the total weight of the installation could be cut down as low as $50 \%$ that of the traditional metal-made SCs with a free lunch of less service personnel involved [2].

Evaluation by the method of the Life Cycle Assessment (LCA) of polymer flat collectors, performed by Chen [3], Doroshenko [4], and Carlsson et al. [5] for flat metal-, flat polymer-made and vacuum collectors demonstrates a positive impact on ecology when polymeric materials are being used in comparison with traditional ones.

\section{Main trends of improvement for liquid-based SCs}

There exists a number of polymeric materials, which all have different characteristics and distinctive price brackets. For use in the solar energy capture systems
(SECS) the stability requirements of various kinds in the operating environment are being put forward. The researches have already gained some experience to profile the most promising polymeric materials for such systems [6-8]. With the emerging technologies and further advances in chemistry, the existing ones and yet new polymers are in a constant state of continuous re-improvement. It normally depends on the additives and the particulars of a manufacturing process to shift the polymer characteristics towards a particular set of desired qualities, such as improved UV-resistance or heightened thermal stability (withstanding a high temperature) as well as durability. PC is such an example: within a year untreated it oxidizes fast and then breaks in pieces, whereas protected by UV-coating it endures $\sim 10$ years of service [9].

The question of transitioning from metallic to polymeric SC components was studied earlier in the Odesa State Academy of Refrigeration (OSAR) by Shestopalov [10] and Kosteniuk [11]. They were sequentially replacing:

- the glass transparent cover with a polymeric plate (transitioning from an aluminium SC-A towards a metalpolymeric SC-C) [10];

- the traditional pipe register (as a heat absorber) with a hollow-channel polymeric plate (transitioning from the metal-polymeric SC-C towards an air-gap-polymeric SC-P) [10];

- the traditional air gap with an air-channeledpolymeric plate (transitioning from the air-gap-polymeric SC-P towards an air-gapless-polymeric PSK-1) [11].

The schematic representation of the SCs-w studied by Shestopalov (the metal [aluminium] SC-A; the metalpolymeric SC-C) and Kosteniuk (the air-gapless-polymeric PSK-1) is shown in Figure 1Ошибка! Источник ссылки не найден.

\section{Heat absorber}

The polymers used for a heat absorber in the solar energy capture systems must meet the following requirements:

- resistance to high temperature and pressure (for systems working under pressure);

- resistance to hot water or applied working fluid exposure;

- low absorber-wall thermal resistance;

- low water-absorption.

The following thermoplastics have received a wide practical application (both in research and industrial designs) for production of a heat absorber: PC [2; 12], ABS [13], NORYL ${ }^{\circledR}$ (PPO) [14], PB, PVC with and without additives, PP-R [15; 16], HDPE [17], PE [18], PP [19; 20], PA, PS, PPS and its various modifications [21].

An experimental study of the effects of hot air and hot water was carried out on the following plastics, which were identified as most durable against exposure to the above: MDPE [7], PE-X [22], PP-B [23], PA66 [24], PA12 [25] 

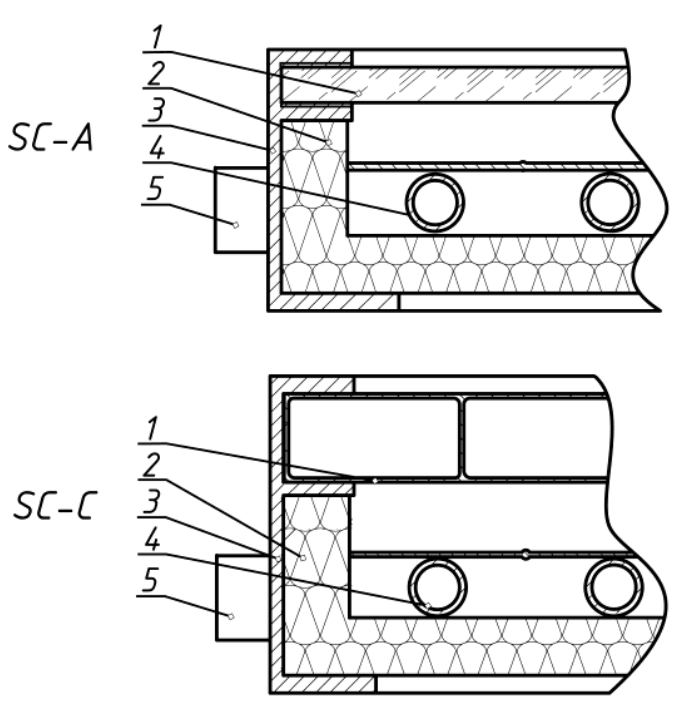

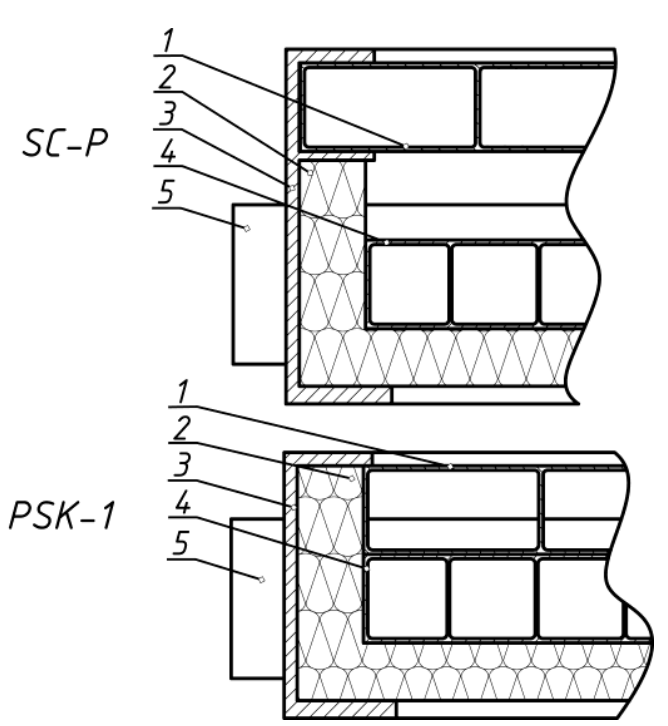

Figure 1 - The schematic representation of the SCs studied in the OSAR.

\section{Transparent cover}

A transparent cover made from polymeric materials must meet the following requirements: high light transmittance, resistance to degradation upon exposure to UV-radiation and high temperatures, low-level soiling.

In Switzerland, Ruesch and Brunold [22] have tested in open-air the polymeric materials for glazing to determine their resistance to pollution and atmospheric exposure. The following materials were checked: PMMA, PC, FEP, PVF, PU, PVC, ETFE. The testing results revealed that PC and PMMA were suited better for outdoor application, but because the temperature resistance of $\mathrm{PC}\left(130^{\circ} \mathrm{C}\right)$ is greater than of PMMA $\left(90^{\circ} \mathrm{C}\right)$, it is the most preferred material. Despite the above, both polymers are being used for glazing in solar collectors $[20 ; 21]$. Other transparent polymers such as PS, transparent PA, or PU either do not meet the thermal stability requirements or are not viable economically [7].

\section{Comparative data analysis}

Polymeric materials are used not only to create polymeric collectors but also in traditional metal-made collectors to reduce the losses resulting from convection. Polymeric honeycombs, placed between the heat absorber and the transparent cover, are used for these purposes. Experimental data for the metal-made SCs with polymeric parts were obtained in the works of Ghoneim [26] and Kessentini [27]. Kosteniuk [11] has applied a similar concept to a polymeric SC using a hollow-channel polymeric plate to suppress the convection. A comparison of the characteristics of metal SCs with a polymer honeycomb is shown in Fig. 2A

Ghoneim [26] has used honeycomb material placed in the air gap space between the glass cover and the heat absorber of a flat plate solar collector to suppress natural convection. He investigated what an impact honeycomb polymer arrangement in the air gap space might have had on the efficiency of the SC. The advantage of such a construction is the convection suppression. Two distinctive designs were under consideration: with $(\mathrm{w} / \mathrm{hc})$ and without a honeycomb insert (wo/hc). The honeycomb panel has reduced the optical efficiency in negligible manner, paling into insignificance with the achieved reduction of the heatloss coefficient.

Kessentini et al. [27] have proposed the numerical model for optimizing the design of an aluminium-made collector. To reduce convective losses and weight, a polymer honeycomb was situated between the transparent cover and the heat absorber as alternative to (instead of) the specially made a double glass with capillary tubes. The bottom part contained a thermally controlled ventilation duct for protection against stagnations. By analysing the simulation results, the optimal geometric characteristics of the heat absorber were proposed and the SC prototype was created. The optimal linear dimensions of the collector were as follows: insulation thickness as of $60 \mathrm{~mm}$, the height of a honeycomb insert $-80 \mathrm{~mm}$, while that of a gap between a heat absorber and a honeycomb insert $-15 \mathrm{~mm}$, and of the ventilation channel $-20 \mathrm{~mm}$.

Numerous studies have been conducted to determine the efficiency of the polymer-made solar collectors. The collectors' technical description is being provided below and summarized in Table 1 . The efficiency curve of the listed collectors could be found in Fig. 2A and 2B.

Shestopalov [10] was studying the modifications of a traditional solar water-thermal collector with the hollowchannel polymeric plate in the absorber and in the transparent cover design. He has replaced the traditional glass cover with a 4-mm hollow-channel polymeric plate (SC-C), and then exchanged its heat absorber with a $8-\mathrm{mm}$ honeycomb polymer plate (SC-P). The comparison showed that the use of polymeric materials in solar collectors reduces the efficiency at most by $14 \%$, compared to an aluminium solar collector (SC-A).

Ariyawiriyanan et al. [15] have tested the unglazed SCs in Thailand with various working areas, made out of the 5 (five) kinds of thermoplastics: PVC-B, PB, PP-R of $1,3 \mathrm{~m} 2$, and PVC-CB, PVC-CB1 of $1,8 \mathrm{~m} 2$ and $2 \mathrm{~m} 2$ accordingly. The result of their tests was that the authors have proposed to use the material with the highest thermal conductivity. They have also found the relation between the size of the SC working area and its efficiency. PVC-CB1 
had exhibited a better characteristics, probably due to the particulars of its channel-gapless design of the heat absorber.

Cristofari et al. [2] have studied the thermal behaviour of the honeycomb-copolymer-made solar collector. They developed a nodal mathematical model to track the various parameter's contribution to the SC's overall efficiency. The modelled theoretical system would have a yearly mean efficiency of $56.5 \%$ - with the wind speeds at $0 \mathrm{~m} / \mathrm{s}$, and that of $49.0 \%$ - with the wind speeds around $5 \mathrm{~m} / \mathrm{s}$ (see Cristofari AugV5 in Fig. 2B, data approximated from readability). Moreover, they have also reported the SC's weight reduction by $50 \%$ versus the traditional flat-plate solar collector.

Sandnes B. и Rekstad J. [14] have devised a combined thermal and photovoltaic solar energy collector based on modified PPO plastics. In their study the efficiency of the photovoltaic/thermal (PV/T) solar collector with (PV/Tg) and without $(\mathrm{PV} / \mathrm{T})$ transparent cover was examined. According to the obtained results, a transparent cover reduces the heat losses coming from the SC's top part, while at the same time and to the lesser extent increasing reflective losses.

Ehrenwirth et al. [13] have produced the polymeric SC coated by glass. The heat absorber they were using was formed in the Twin-Sheet-Thermoforming manufacturing process and tested according to EN ISO 9806:2013 (Solar energy - Solar thermal collectors - Test methods). The tested prototype has demonstrated a better efficiency than those of commercial origin, and a similar efficiency in comparison with the described prototypes in the existing literature.

Matrinopoulos G. et al. [12] have used computational fluid dynamics (CFD) in order to approximate the fluid's heat distribution transfer function and to compute its effective velocity along the channels of the heat chamber. The heat-carrying fluid of a black colour was employed as the working medium. The authors denoted the importance of the effective inlet's configuration. Their field data (Martinopoulos exp. in Fig. 2B) were in agreement with the results obtained from modelling.

Missirlis et al. [28] were studying various arrangements of the hydraulic collector's inlet with a view to improve their polymeric SC's output efficiency. It had a single layer formed by a PC-plate over its honeycomb PC heat absorber. For improved solar energy absorption the used working liquid was a mixture of black ink diluted by water. The results demonstrated that a simple rearrangement of the hydraulic collector's in- and outlets can boost the SC's characteristics for no added costs in production. The best efficiency was demonstrated to be exhibited by their 3rd layout design, where the heat absorber's input and output pipes were going along the heat absorber (case 3 in Fig. 2B).

Kosteniuk [26] has researched several modifications of the polymeric SCs made from a hollow-channel polymeric plate: with a transparent cover, having an air gap (SC-P in Fig. 2) and the air-gapless type (PSK-1 in Fig. 2), both the collectors' transparent covers were $4 \mathrm{~mm}$ thick. The experimental results for the PSK-1 monoblock structure had a slight decrease in efficiency due to a large number of transverse walls in the $4 \mathrm{~mm}$ panel. Despite this, the construction has a greater rigidity and a smaller thickness.

The relationships in Figure 2B for the polymeric SCs show that the use of polycarbonate gives a better efficiency when compared against the other materials, what could be explained as forming a thermal resistance of a lesser degree by thinning the walls.

Table 1 - Properties of polymeric collectors

\begin{tabular}{|l|l|l|l|l|l|l|l|l|}
\hline Authors & Area, $\mathrm{m}^{2}$ & $\begin{array}{l}\text { HA } \\
\text { material }\end{array}$ & $\begin{array}{l}\text { TC } \\
\text { material }\end{array}$ & $\begin{array}{l}\text { Insulation } \\
\text { thickness, } \\
\text { mm }\end{array}$ & $\begin{array}{l}\text { Insulation } \\
\text { material }\end{array}$ & $\begin{array}{l}\text { HA } \\
\text { thickness, } \\
\text { mm }\end{array}$ & $\begin{array}{l}\text { TC } \\
\text { thickness, } \\
\text { mm }\end{array}$ & $\begin{array}{l}\text { Air } \\
\text { gap, } \\
\text { mm }\end{array}$ \\
\hline Ariyawiriyanan [15] & $1.3 ; 1.8 ; 2$ & $\begin{array}{l}\text { PVC-B, } \\
\text { PB, PP-R, } \\
\text { PVC-CB, } \\
\text { PVC-CB1 }\end{array}$ & & & & & & \\
\hline Cristofari [2] & 2 & PC & G & 30 & חY & 10 & 4 & - \\
\hline $\begin{array}{l}\text { Sandnes and Rekstad } \\
{[14]}\end{array}$ & 0.48 & PPO & G & 50 & MW & 10 & 4 & 12 \\
\hline $\begin{array}{l}\text { Shestopalov (SC-P) } \\
{[10]}\end{array}$ & 1.16 & PC & PC & 20 & MW & 8 & 4 & 16 \\
\hline $\begin{array}{l}\text { Kostenyk } \\
\text { (PSK-1) [11] }\end{array}$ & 1.16 & PC & PC & 20 & MW & 10 & 4 & \\
\hline $\begin{array}{l}\text { Missirlis [28], } \\
\text { Matrinopoulos [12] }\end{array}$ & 1.3 & PC & PCP & $\begin{array}{l}\text { BP - 10, } \\
\text { EP - 30 }\end{array}$ & $\begin{array}{l}\text { PC+nanogel, } \\
\text { PU }\end{array}$ & 10 & 3 & - \\
\hline Ehrenwirth [13] & 1.32 & ABS & G & 30 & PU & 8 & 4 & - \\
\hline
\end{tabular}

Keys: PC — polycarbonate; PCP — plate-type polycarbonate; G — glass, PU — polyurethane; MW — mineral wool; BP — bottom part; EP — side part; «-» - no data; «»-characteristics are not available due to construction 


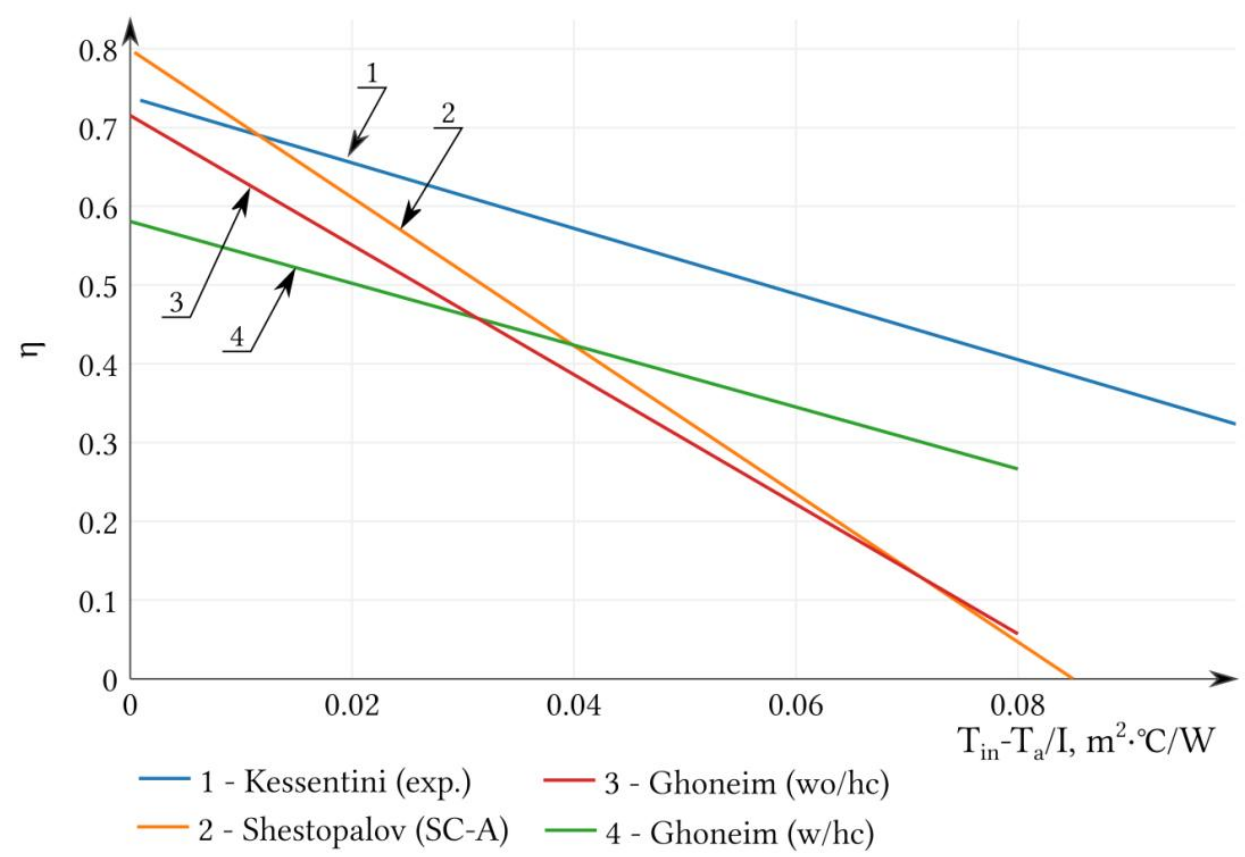

Keys: $\eta$ - the coefficient of efficiency, I - solar received irradiation, $\mathrm{W} / \mathrm{m}^{2}$, $\mathrm{T}_{\mathrm{a}}$ - ambient temperature, ${ }^{\circ} \mathrm{C}, \mathrm{T}_{\mathrm{in}}$-temperature at the inlet, ${ }^{\circ} \mathrm{C}$.

Figure 2A - Efficiency curve for metal (A) and polymer (B) solar collectors

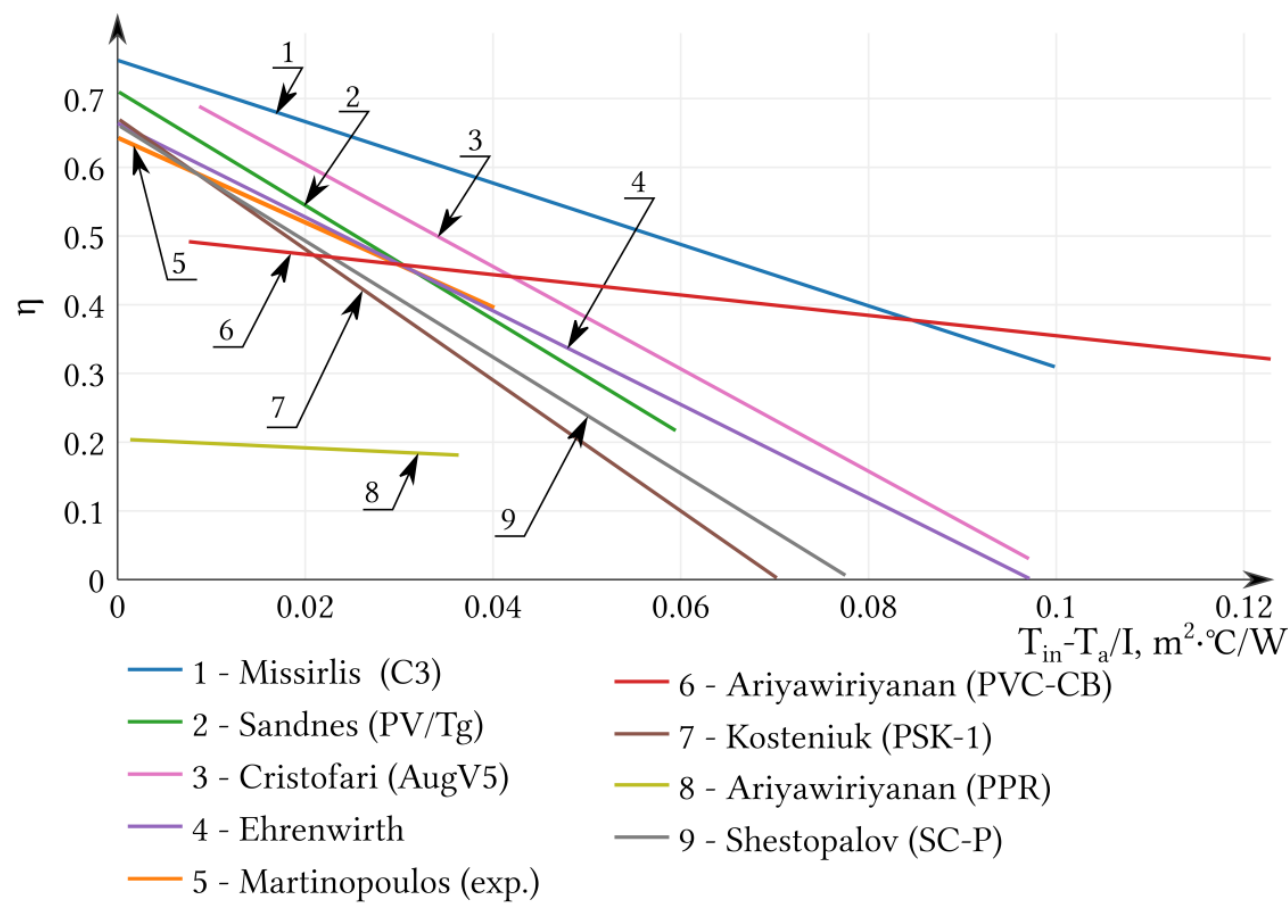

Figure $2 \boldsymbol{B}$ - Efficiency curve for polymeric SCs (Figure 2A's keys)

\section{Development of new solutions for polymeric SCs-w and the objectives of further research.}

The authors consider further improvement of the polymeric SCs-w, in particular, its assembly realisation with the suggestions found in the above-cited research $[2,12-$ $15,28]$ and those made earlier in the OSAR studies [10, 11].

The main approach to solve the problems under consideration would be to implement the planned cycle of theoretical and experimental research. The authors has conducted a preliminary analysis of the summary heat losses in liquid-based solar collectors (Fig. 3), which are thought to be the result of convection and heat radiation. The main parameters' dependencies, which are material to the performance of the polymeric SCs, were determined as: the size of the air gap between a heat absorber and its transparent cover (A), the wind speeds at the place of a SC installation (B), the number of transparent layers (C) and 
insulation thickness (D). The A,B, D parameters were obtained for a double-layered (of 10-mm separation) SC with the air gap of $20 \mathrm{~mm}$, insulation of $30 \mathrm{~mm}$, and the SC's angle of slope of $42^{\circ}$.

The convective heat transfer coefficient is calculated by

$$
h=N u \frac{k}{L}
$$

where $\mathrm{k}$ - thermal conductivity $[\mathrm{W} / \mathrm{m} \mathrm{K}], \mathrm{L}$ - plate spacing [m].

The radiation heat transfer (RHT) coefficient from plate to the first cover (Eq. (3.1)), between plates and to the ambient in Eq (3.2) is calculated by:

$$
\begin{gathered}
h_{r, p-c 1}=\frac{\sigma \varepsilon_{c}\left(T_{p}+T_{c 1}\right)\left(T_{p}^{2}+T_{c 1}^{2}\right)}{\frac{1}{\varepsilon_{p}}+\frac{1}{\varepsilon_{c 1}}-1} \\
h_{r, c 2-a}=\frac{\sigma \varepsilon_{c}\left(T_{c 2}+T_{s}\right)\left(T_{c 2}^{2}+T_{s}^{2}\right)\left(T_{c 2}-T_{s}\right)}{T_{c 2}-T_{a}},
\end{gathered}
$$

where $\sigma-$ the Stefan-Boltzmann constant $\left(\mathrm{W} \cdot \mathrm{m}^{-2} \cdot \mathrm{K}^{-4}\right), \varepsilon-$ emittance, $\mathrm{T}$ - temperature $(\mathrm{K})$ and the indices: $\mathrm{c}$-cover, $\mathrm{p}$ - plate, $\mathrm{s}$ - sky, a - ambient.

For parallel plates the correlation of Hollands et al. (29) is used, which relates Nusselt number and Rayleigh number for tilt angles from $0^{\circ}$ to $75^{\circ}$.
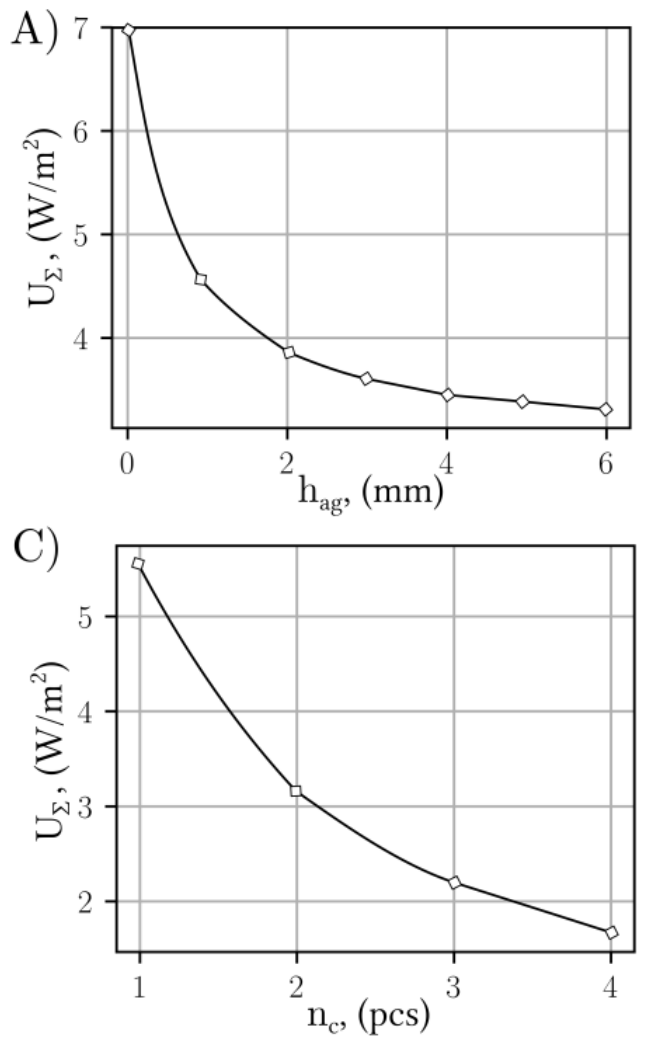

$N u=1+1.44\left(1-\frac{1708(\sin 1.8 \beta)^{2.6}}{R a \cos \beta}\right)\left(1-\frac{1708}{R a \cos \beta}\right)^{+}\left(\left(\frac{R a \cos \beta}{5830}\right)^{1 / 3}-1\right)^{+}$

where the + exponent means that only positive values are to be considered and zero is to be used for negative values, $\beta$ - collector tilt (deg), Ra - Rayleig number.

Convection heat loss coefficient from the top glazing exposed to wind is calculated using McAdams correlation [30] given by:

$$
h_{w}=5.7+3.8 \cdot w
$$

where $\mathrm{w}$ - wind speed $(\mathrm{m} / \mathrm{s})$

The resistance to the surroundings:

$$
R=\frac{1}{h_{w}+h_{r, c 2-a}}
$$

where $\varepsilon$ - convection heat loss coefficient from the top glazing exposed to wind.

For two cover system, the top loss coefficient from the collector plate to the ambient is:

$$
U_{t}=\frac{1}{R_{1}+R_{2}+R_{3}}
$$

Overall loss coefficient

$$
U_{\Sigma}=U_{\text {top }}+U_{\text {bottom }}+U_{\text {edge }}
$$

B)

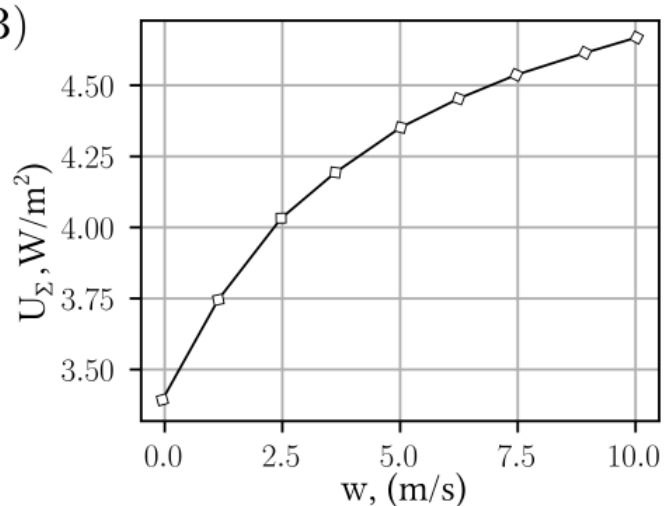

D)

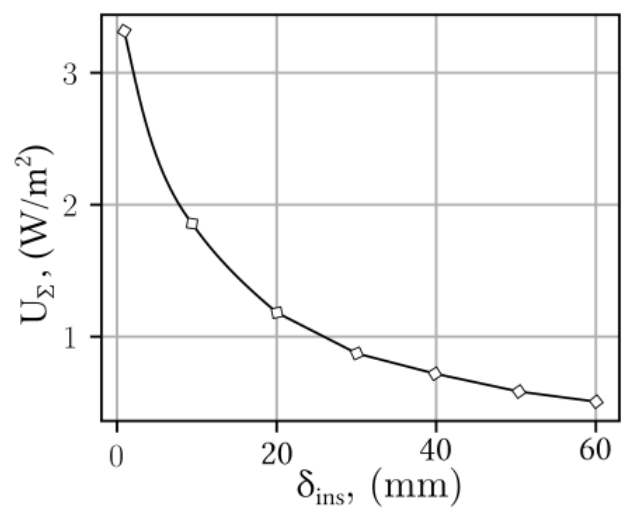

Figure 3 - Dependence of top loss coefficient on: air gap between heat absorber and transparent cover (A), wind speed (B), number of transparent covers (C), insulation thickness (D). 


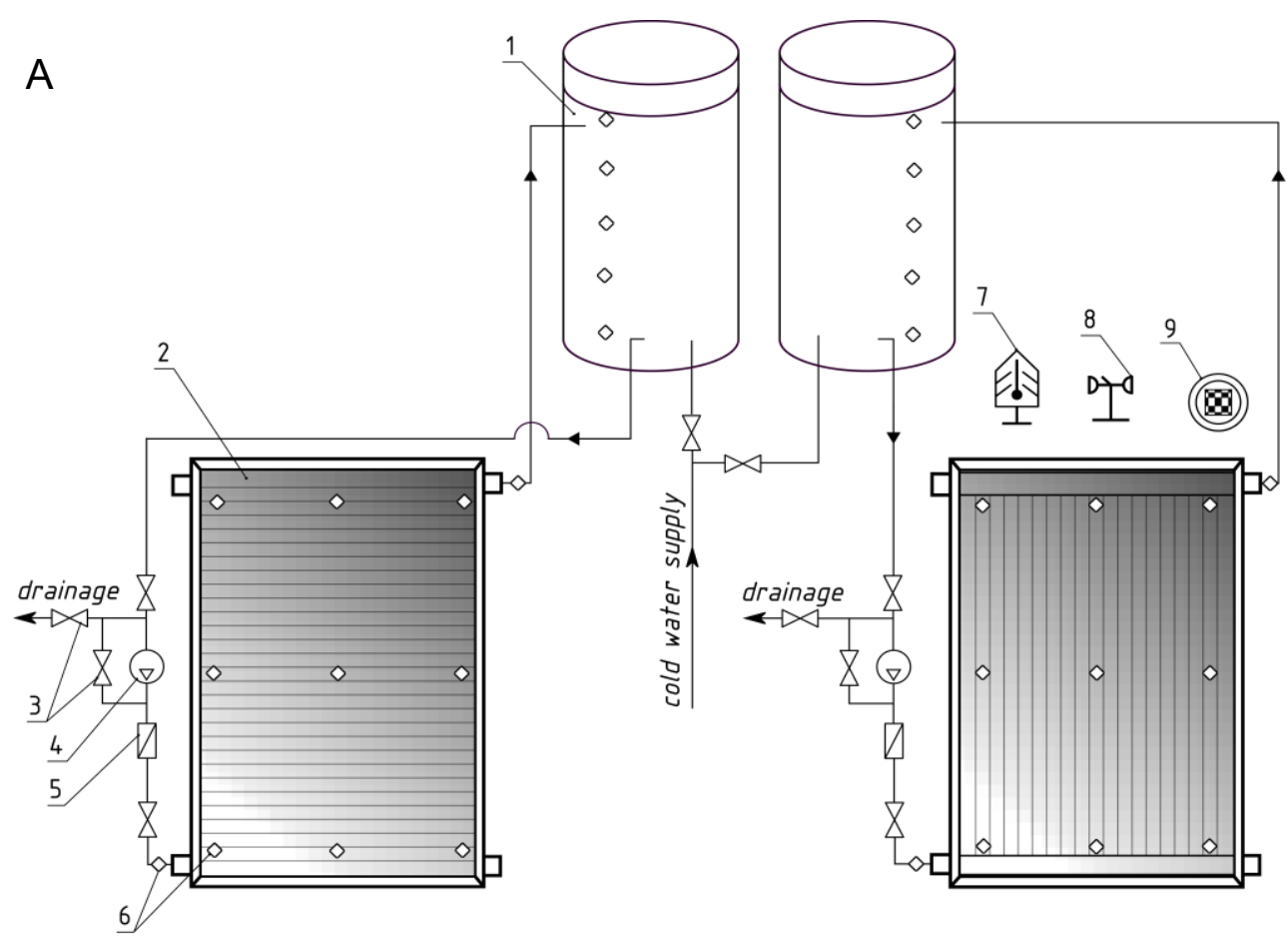

Б

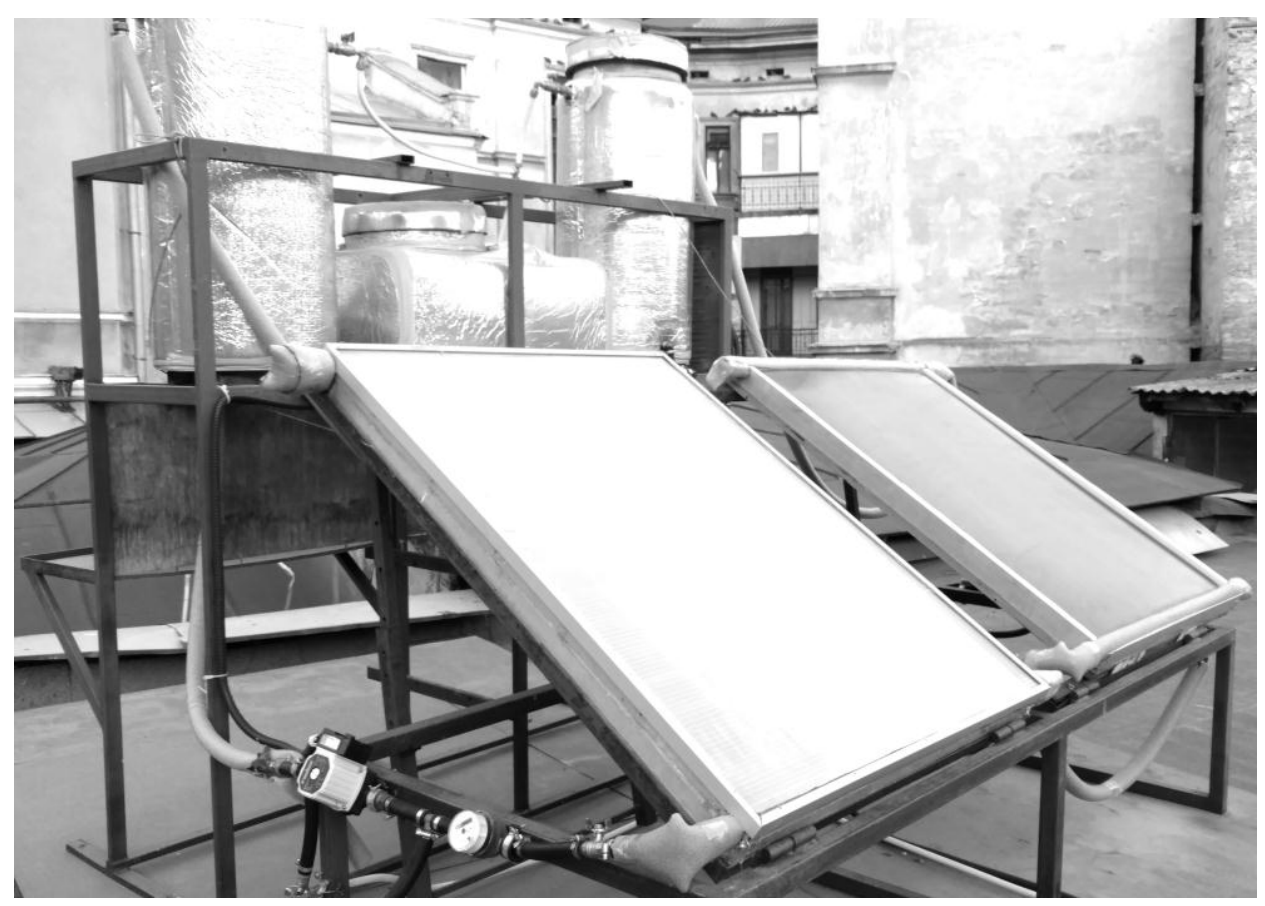

Keys: 1- thermo-insulated polymeric HWT, 2- polymeric SC-w, 3 - globe valve, 4 - water pump, 5 - flow meter, 6 - thermal sensors, 7 - ambient temperature thermal sensor, 8 - anemometer, 9 - pyranometer.

Figure 4 - Principal schematics (A) and the photo (B) of the experimental installation.

For testing of new solution the experimental installation was modernized (Fig. 4). Its purpose is for comparative analysis of new SCs under the same conditions. Main trends for improvement of the polymeric modifications of the water-based SCs are:
- elimination of an air-gap between a heat absorber and its transparent cover as well as the creation of the monoblock SCs; it is of importance to optimize the flow channels geometry of the SCs transparent cover; air circulation is expected to reduce the summary heat losses; 
- optimization of the polymeric SC heat absorber channel sizes, including the form and the size of a hydraulic collector; its interconnection matters also;

- experimental study of water-distribution factor and its evenness in the heat absorber channels, aiming at an increase of the polymeric SC efficiency and its elements' thermal-shock prevention; the foundation of this part of the research was laid earlier in the OSAR in the theoretical studies [4].

\section{Conclusions}

1. As the result of the above performed review of the bibliography cited, further improvement of the liquid-based SCs is to be in the reference direction of more extensive use of polymeric materials in its main parts; it is chosen by the authors for a heat absorber and for its transparent cover the UV-stabilized PC as the most accessible material on the market which meets the requirements.

2. The air-gapless installation comprising the heat absorber and its transparent cover is currently being scheduled, with the plans being put forth under consideration of a monoblock polymeric SC for assembly; with this it would be of certain importance to optimize further the flow channels of its transparent cover and those of the heat absorber.

\section{References}

1 'London Metal Exchange: Non-ferrous'. [Online]. Available: https://www.lme.com/en-GB/Metals/Nonferrous/. [Accessed: 01-Dec-2018].

2 C. Cristofari, G. Notton, P. Poggi, and A. Louche, 'Modelling and performance of a copolymer solar water heating collector', Solar Energy, vol. 72, no. 2, pp. 99-112, Feb. 2002. https://doi.org/10.1016/s0038-092x(01)00092-5 3 G. Chen, A. Doroshenko, P. Koltun, and K. Shestopalov, 'Comparative field experimental investigations of different flat plate solar collectors', Solar Energy, vol. 115, pp. 577588, May 2015. https://doi.org/10.1016/j.solener.2015.03.021 4 A. Doroshenko, K. Shestopalov, I. Mladionov, V. Goncharenko, and P. Koltun, 'Polymeric materials for solar energy utilization: a comparative experimental study and environmental aspects', Refrigeration Engineering and Technology, vol. 52, no. 3, Aug. 2016, pp. 16-24. https://doi.org/10.15673/ret.v52i3.118

5 B. Carlsson, H. Persson, M. Meir, and J. Rekstad, 'A total cost perspective on use of polymeric materials in solar collectors - Importance of environmental performance on suitability', Applied Energy, vol. 125, pp. 10-20, Jul. 2014. 6 R. Raman, S. Mantell, J. Davidson, C. Wu, and G. Jorgensen, 'A Review of Polymer Materials for Solar Water Heating Systems', Journal of Solar Energy Engineering, vol. 122, no. 2, pp. 92-100, 2000. Doi: https://doi.org/10.1115/1.1288214

7 M. Köhl, M. G. Meir, P. Papillon, G. M. Wallner, and S. Saile, Eds., Polymeric Materials for Solar Thermal Applications. Wiley-VCH Verlag $\mathrm{GmbH} \& \mathrm{Co}$. KGaA, 2013.

8 A. C. Gladen, J. H. Davidson, and S. C. Mantell, 'The Effect of a Thermotropic Material on the Optical Efficiency and Stagnation Temperature of a Polymer Flat Plate Solar Collector', J. Sol. Energy Eng, vol. 137, no. 2, pp. $021003-$ 021003-6, Sep. 2014. https://doi.org/10.1115/1.4028366

9 M. Kutz, Handbook of Environmental Degradation of Materials, 3 edition. S.1.: William Andrew, 2018.

$10 \mathrm{~K}$. Shestopalov, 'Teplotekhnichni kharakteristiki polimernikh sonyachnikh kolektoriv dlya sistem teplopostachannya', dis. na zdobuttya nauk. stupenya kand. tekhn. nauk: 05.14.06, Odesa State Academy of Refrigeration, Odesa, 2005.

11 V. Kosteniuk, 'Pidvishchennya efektivnosti polimernikh sonyachnikh kolektoriv ta sistem teplokholodopostachannya', avtoref. dis. na zdobuttya nauk. stupenya kand. tekhn. nauk: 05.05.14., Odesa State Academy of Refrigeration, Odesa, 2012.

12 G. Martinopoulos, D. Missirlis, G. Tsilingiridis, K. Yakinthos, and N. Kyriakis, 'CFD modeling of a polymer solar collector', Renewable Energy, vol. 35, no. 7, pp. 1499-1508, Jul. 2010. Doi: https://doi.org/10.1016/j.renene. 2010.01.004

13 M. Ehrenwirth, V. Albert-Seifried, D. Beckenbauer, M. Klärner, C. Trinkl, and W. Zörner, 'Theoretical and Experimental Investigation of Polymeric Solar-Thermal Flat-Plate Collectors', in ISES Solar World Congress 2017, 2017.

14 B. Sandnes and J. Rekstad, 'A photovoltaic/thermal (PV/T) collector with a polymer absorber plate. Experimental study and analytical model', Solar Energy, vol. 72, no. 1, pp. 63-73, Jan. 2002. Doi: https://doi.org/10.1016/s0038-092x(01)00091-3

15 W. Ariyawiriyanan et al., 'Thermal Efficiency of Solar Collector Made from Thermoplastics', Energy Procedia, vol. 34, pp. 500-505, Jan. 2013. Doi: https://doi.org/10.1016/j.egypro.2013.06.778

16 'Ocean ${ }^{\circledR}$ Solar absorber 40', Peraqua, 01-Dec-2018. [Online]. Available at: http://www.peraqua.com/en/product/ solar-absorber-40. [Accessed: 01-Dec-2018].

17 M. Wunder, 'PoolRipp. Solar pool absorber', 2016. [Online]. Available: https://pooldoktor.at/solarabsorberpool.html. [Accessed: 01-Dec-2018].

18 'Final Report Summary - SCOOP (Solar Collectors made of Polymers) | Report Summary | SCOOP | FP7', CORDIS | European Commission, 15-Nov-2018. [Online]. [Accessed: 01-Dec-2018] Available: https://cordis.europa. eu/result/rcn/173112_en.html

19 'Magen eco energy. eco-Spark solar collector', 01-Dec2018. [Online]. Available: https://www.magenecoenergy.com/eco-spark/. [Accessed: 01-Dec-2018].

20 S. Kahlen, G. M. Wallner, and R. W. Lang, 'Aging behavior of polymeric solar absorber materials - Part 2: Commodity plastics', Solar Energy, vol. 84, no. 9, pp. 1577-1586, Sep. 2010. Doi: https://doi.org/10.1016/ j.solener.2010.04.007

21 M. Povacz et al., "Novel Solar Thermal Collector Systems in Polymer Design - Part 3: Aging Behavior of PP Absorber Materials', Energy Procedia, vol. 91, pp. 392 402, Jun. 2016. Doi: https://doi.org/10.1016/j.egypro. 2016.06.280

22 J. Fischer, P. R. Bradler, M. Schlaeger, G. M. Wallner, and R. W. Lang, 'Novel Solar Thermal Collector Systems in Polymer Design - Part 5: Fatigue Characterization of Engineering PA Grades for Pressurized Integrated Storage Collectors', Energy Procedia, vol. 91, pp. 27-34, Jun. 2016. 
23 S. Kahlen, G. M. Wallner, and R. W. Lang, 'Aging behavior of polymeric solar absorber materials - Part 1: Engineering plastics', Solar Energy, vol. 84, no. 9, pp. 1567-1576, Sep. 2010. Doi: https://doi.org/10.1016/ j.solener.2010.03.021

24 F. Ruesch and S. Brunold, 'Langzeituntersuchung an abdeckungsmaterialien für thermische sonnenkollektoren', Bundesamt für Energie, Bern, Impressum BFE 43729, 2008.

25 'Technical data sheet. AventaSolar collector Vertical65', Aventasolar solar heating company, 2016. [Online]. Available: http://aventasolar.com/wp-content/ uploads/2016/11/TDS_AVENTASOLAR_collector65V_v5 _3_041115.pdf. [Accessed: 01-Dec-2018].

26 A. A. Ghoneim, 'Performance optimization of solar collector equipped with different arrangements of squarecelled honeycomb', International Journal of Thermal Sciences, vol. 44, no. 1, pp. 95-105, Jan. 2005. Doi: https://doi.org/10.1016/j.ijthermalsci.2004.03.008

27 H. Kessentini, J. Castro, R. Capdevila, and A. Oliva,
'Development of flat plate collector with plastic transparent insulation and low-cost overheating protection system', Applied Energy, vol. 133, pp. 206-223, Nov. 2014. Doi: https://doi.org/10.1016/j.apenergy.2014.07.093

28 D. Missirlis, G. Martinopoulos, G. Tsilingiridis, K. Yakinthos, and N. Kyriakis, 'Investigation of the heat transfer behaviour of a polymer solar collector for different manifold configurations', Renewable Energy, vol. 68, pp. 715-723, Aug. 2014. Doi: https://doi.org/10.1016/ j.renene.2014.03.008

29 K. G. T. Hollands, T. E. Unny, G. D. Raithby, and L. Konicek, 'Free Convective Heat Transfer Across Inclined Air Layers', J. Heat Transfer, vol. 98, no. 2, pp. 189-193, May 1976. Doi: https://doi.org/10.1115/1.3450517

30 J. A. Duffie and W. A. Beckman, Solar Engineering of Thermal Processes, 4th ed. John Wiley \& Sons, 2013.

Received 05 July 2018 Approved 04 September 2018 Available in Internet 30 October 2018 